Technical Paper

\title{
Estimation of Improved Energy Balance of Anaerobic Digestion Plant by Hyper Thermal Hydrolysis
}

\author{
Shojiro Osumi, and Jun TsubOTA
}

(Received February 17, 2009)

\author{
超高温可溶化技術導入によるメタン発酵施設のエネルギーバランス改善試算 \\ 大隅省二郎，坪田 潤
}

\begin{abstract}
Anaerobic digestion recovers renewable energy from garbage of municipal solid waste, which is not suitable for incineration because of its high water content. However, anaerobic digestion produces digestion residue and high BOD waste water. Adaptation of hyper thermal hydrolysis to dry type anaerobic digester does not require water treatment process, therefore increased the amount of electricity recovery. In this study, we calculated and compared the amount of surplus energy produced by standard methane fermentation and hyper thermal hydrolysis integrated process.
\end{abstract}

\section{Key Words}

Biogas, Hyper thermal hydrolysis, Methane fermentation, Energy balance

\section{1. はじめに}

メタン発酵は，生ごみ等，含水率が高いため焼却処理に向 かず，またその性状からマテリアルリサイクルも難しいバイ オマスから，バイオガスとして効率よくエネルギー回収する ことができる技術である11。しかし，投入バイオマス中の固形 物の10 40\%程度は発酵残渣として，また投入バイオマス中 の水分（通常 $70 \sim 95 \%$ 程度）はBOD10,000mg/L 程度の排水 として排出されるため ${ }^{2)}$, これらの処理がメタン発酵普及に とって最大のネックとなっている。そのため, 発酵残渣発生 量及び廃水処理量を削減することができれば，メ夕ン発酵の 普及を急速に促進できる可能性がある ${ }^{3)}$ 。

我々が開発した超高温可溶化技術は, 高温メタン発酵污泥 中の微生物を超高温 $\left(80^{\circ} \mathrm{C}\right)$ で利用することにより, 難分解 性有機物の可溶化を促進し，バイオガス回収量の増大と発酵 残渣の削減を実現するものである ${ }^{4)}$ が，分解率が高いために pHが比較的高く，かつ高温であるという本技術の特徴を利用 し，超高温可溶化槽においてアンモニアストリッピングを施 し, メタン発酵プロセスで発生するアンモニアを蒸発回収す ることが可能となる ${ }^{5)}$ 。

メタン発酵を行う際，固形物濃度が高すぎるために希釈を 要するケースが多く, 希釈水としてメタン発酵から出てくる 排水を再利用できることが好ましいが，生ごみのように窒素 含有濃度の高い廃棄物を原料とする場合, メ夕ン発酵プロセ

Energy Engineering Department, Osaka Gas Co., Ltd.

5-11-61, Torishima, Konohana-ku, Osaka 554-0051, Japan
スにおいて多量のアンモニアが発生し，処理水を再利用する ことでこれが濃縮され，メタン発酵槽内におけるアンモニア 濃度が高くなり，アンモニア阻害によりメタン発酵が継続で きなくなるという問題が生じる6)7)。よって, 処理水を希釈水 として使用する場合には, アンモニア除去等の排水処理を 行った後でないと使用することができない。また, 利用用途 のない排水を河川や下水に放流する場合も，基準を満足する ためにかなり高度な排水処理を必要とする。

一方, 超高温可溶化を導入し, さらに超高温可溶化槽にお けるアンモニアストリッピングを行った場合 ${ }^{8)}$ は, アンモニ アを適度に除去することが可能となり，アンモニアの蓄積が 発生しないため, 排水を処理することなく希釈水として利用 することが可能となる ${ }^{9)}$ 。さらに，アンモニアストリッピング の際に相当量の水が蒸発し, アンモニア水として回収される ことを考慮すると, 河川や下水等に放流しなくてはならない 排水が全く発生せず, 結果として, 全く水処理を必要としな いプロセスが実現できる可能性がある。本プロセスには, 発 酵残渣の発生量も大幅に削減できるというメリットもあり, 実現すれば, メタン発酵普及のネックとなっている発酵残渣 の処分及び排水処理を大幅に軽減することができ，コストの 面からはかなりのメリットがあると期待される。

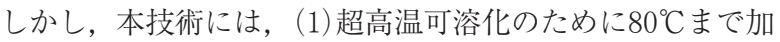
温する必要がある，(2)アンモニアストリッピングのためにブ

\footnotetext{
大阪ガス(株) エネルギー技術部

干 554-0051 大阪市此花区西島 5-11-61
} 
ロワ電力及び気化熱分の熱を加える必要があることから，エ ネルギー収支上は従来技術に劣るのではないかという懸念が あった。一方で，(1)バイオガス回収量が増加する，(2)排水 処理に必要なエネルギーが不要となるといった, エネルギー 収支上もプラスになる要素も含まれるため, 従来技術と本技 術のどちらがエネルギー収支上優れているかを直観的に判断 することは難しい。

そこで, 本研究では, 排水処理を含めたエネルギー収支を 評価することにより, 超高温可溶化を導入することでエネル ギーバランス改善効果があるのかどうかを明らかにする。

\section{2. 方 法}

\section{1 想定フロー}

本試算では，自治体が回収した分別生ごみを焼却場に併設 するメタン発酵施設で処理することを想定した。回収生ごみ の想定組成を Table 1 に示す。

標準の処理フローは, $55^{\circ} \mathrm{C}$ の高温乾式メタン発酵 ${ }^{10)}$ (生ご みをTS $20 \%$ に希釈して投入) 後, 発酵残渣を脱水し, 脱水残 渣は焼却炉へ，脱水ろ液は排水処理後，原料生ごみと同量を 希釈水として利用し, 残りを下水放流するものとした。

超高温可溶化導入ケースは, 同じく $55^{\circ} \mathrm{C}$ 高温乾式メタン 発酵をした後, 後段に $80^{\circ} \mathrm{C}$ の超高温可溶化槽を設け, 全ての 生ごみが計算上 1 回は超高温可溶化槽を通過するようにする ため, 生ごみと同量のメタン発酵処理物が超高温可溶化槽を 通過するシステムとした。超高温可溶化槽では, 回収したバ イオガスを用いてアンモニアストリッピングを行い, アンモ ニア濃度の低くなった超高温可溶化処理液をメ夕ン発酵槽へ 戻すことで, メタン発酵槽内のアンモニア濃度上昇を防ぐシ ステムとした。

Table 1 Assumption of collected garbage

\begin{tabular}{l|l}
\hline Amount & $30 \mathrm{t} / \mathrm{d}$ \\
\hline $\mathrm{TS}$ & $40 \%$ \\
\hline Calorie & $7.6 \mathrm{GJ} / \mathrm{t}$ \\
\hline $\mathrm{T}-\mathrm{N}$ & $0.4 \%$ \\
\hline
\end{tabular}

*TS : Total Solid
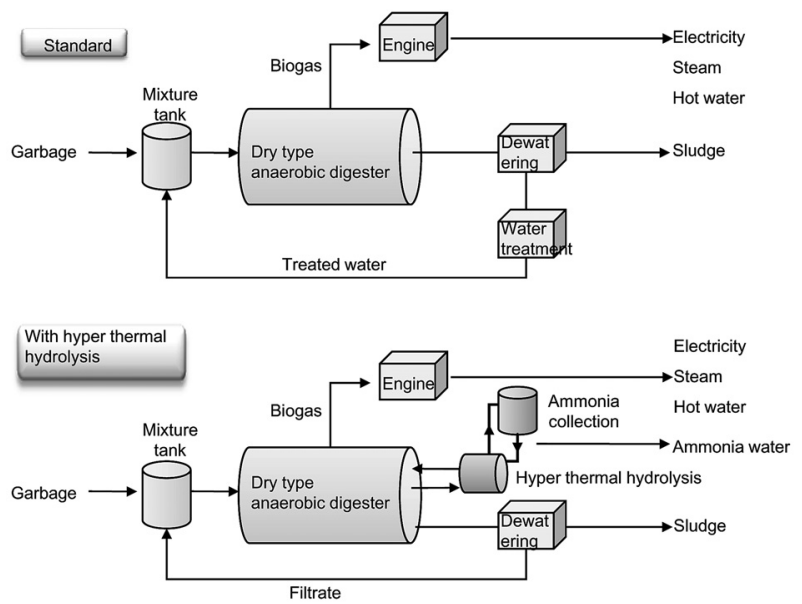

Fig. 1 Assumed treatment flow chart
発酵残渣は標準ケースと同様に脱水し, 脱水残渣は焼却炉 へ，脱水乃液はアンモニア濃度が低くなっており，また，ア ンモニアストリッピングに拈いてアンモニア水として蒸発回 収される水分によってバランスさせることで, 全量希釈水と して利用することとした (Fig. 1 参照)。380 460 $\mathrm{m}^{3} / \mathrm{h}$ 以上 のガス量でアンモニアストリッピングすることで, 脱水ろ液 を希釈水として利用してもアンモニアによる阻害無しにメタ ン発酵を続けることが可能である ${ }^{5)}$ 。

原料の生ごみ及び希釈水は $15^{\circ} \mathrm{C}$ でってくるものとした。

\section{2 プロセスの前提条件}

分別生ごみの標準条件および超高温可溶化導入条件におけ るバイオガス化率は既報 ${ }^{10)}$ を参考にそれぞれ Table 2 の通り とした。

回収バイオガスの組成はメタン $60 \%$ ，二酸化炭素 $40 \%$ と し, 高位発熱量は $0.024 \mathrm{GJ} / \mathrm{m}^{3}$ とした。脱水機のTS回収率, 脱 水残渣の TS はそれぞれ Table 2 の通りとした。

\section{3 物質収支}

2.1 で示したフロー, 2.2 で示した試算条件における物質収 支をFig. 2 に示す。

Fig. 2 に示す通り, 標準条件では36.9t/日の水を処理するこ とが必要であるが, 超高温可溶化を導入した場合は, 超高温 可溶化におけるアンモニアストリッピングの際に水分を10.8t/ 日回収することで水処理は不要となる。 $80^{\circ} \mathrm{C} て ゙$ 蒸発させた水 蒸気を $36^{\circ} \mathrm{C}$ で回収すると想定すると, $10.8 \mathrm{t} /$ 日の水分を回収 するために必要な超高温可溶化槽における通気量は, 以下に より $16,300 \mathrm{~m}^{3} \mathrm{~N} /$ 日となる。

$80^{\circ} \mathrm{C}$ における飽和蒸気圧： $47.4 \mathrm{kPa}$

$80^{\circ} \mathrm{C}$ における比容積 : $3.41 \mathrm{~m}^{3} / \mathrm{kg}$

$36^{\circ} \mathrm{C}$ に打ける飽和蒸気圧 : $5.6 \mathrm{kPa}$

$36^{\circ} \mathrm{C}$ における比容積 : $24.0 \mathrm{~m}^{3} / \mathrm{kg}$

$80^{\circ} \mathrm{C}$ でガス中に存在する水蒸気量（重量, 体積)

: Ws $80 \mathrm{~kg} /$ 日, Vs80 $\mathrm{m}^{3} \mathrm{~N} /$ 日

$36^{\circ} \mathrm{C}$ でガス中に存在する水蒸気量（重量, 体積)

: Ws $36 \mathrm{~kg} /$ 日, $\mathrm{VS}_{\mathrm{S} 36 \mathrm{~m}_{3} \mathrm{~N} / \text { 日 }}$

ストリッピングガス量 $: \mathrm{V} \mathrm{m}^{3} \mathrm{~N} /$ 日

とすると，

$\mathrm{Vs}_{\mathrm{s}} \mathrm{m}=\mathrm{V} \times(273+80) / 273 \times 101.3 /(101.3-47.4)=3.41 \mathrm{WS}_{80}$

$\mathrm{VS} 36 \mathrm{~m}=\mathrm{V} \times(273+36) / 273 \times 101.3 /(101.3-5.6)=24.0 \mathrm{WS}_{36}$

$\mathrm{WS}_{80}-\mathrm{WS}_{36}=10.8$

また，発酵残渣は，標準条件で14.0t/日発生するのに対し，

Table 2 Conditions precedent of treatment process

\begin{tabular}{l|l}
\hline Gasification efficiency (standard) ${ }^{10)}$ & $82 \%$ \\
\hline $\begin{array}{l}\text { Gasification efficiency (with hyper thermal } \\
\text { hydrolysis) }^{10)}\end{array}$ & $90 \%$ \\
\hline Calorie of biogas & $0.024 \mathrm{GJ} / \mathrm{m}^{3}$ \\
\hline Recovery ratio of TS by dewatering equipment & $90 \%$ \\
\hline TS of dewatered sludge & $25 \%$ \\
\hline
\end{tabular}




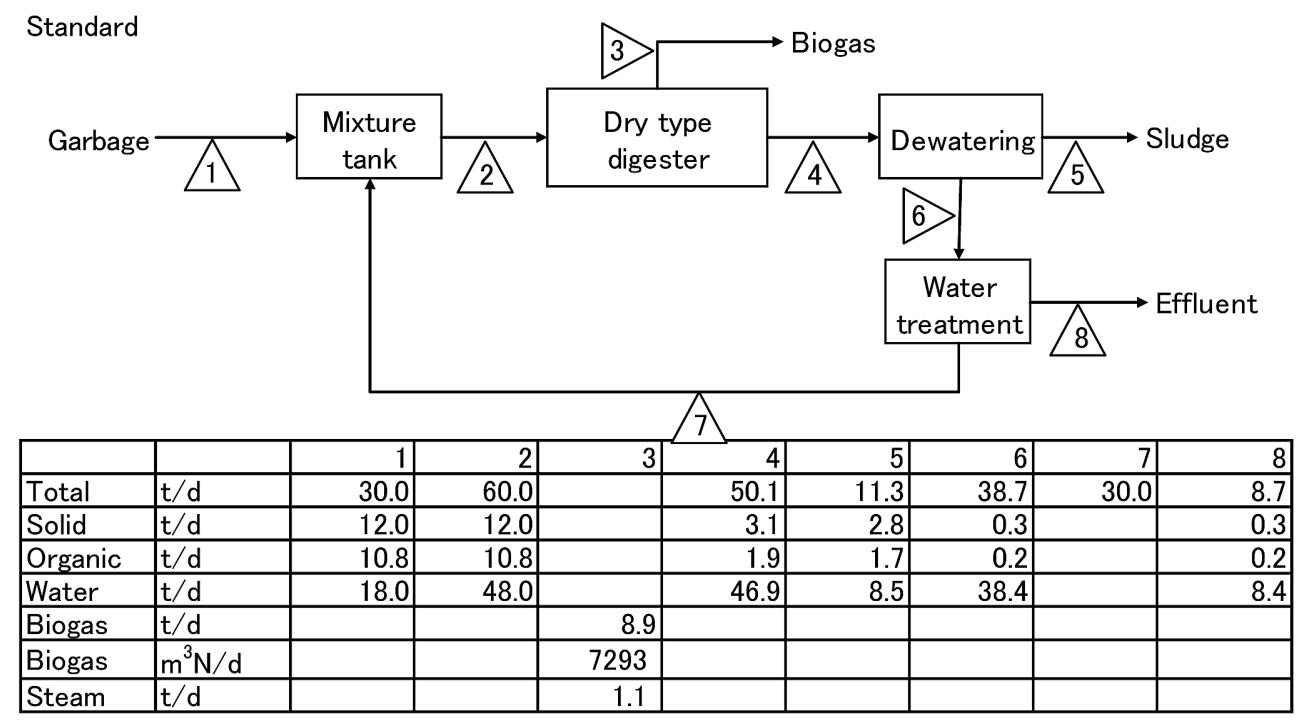

With hyper thermal hydrolysis

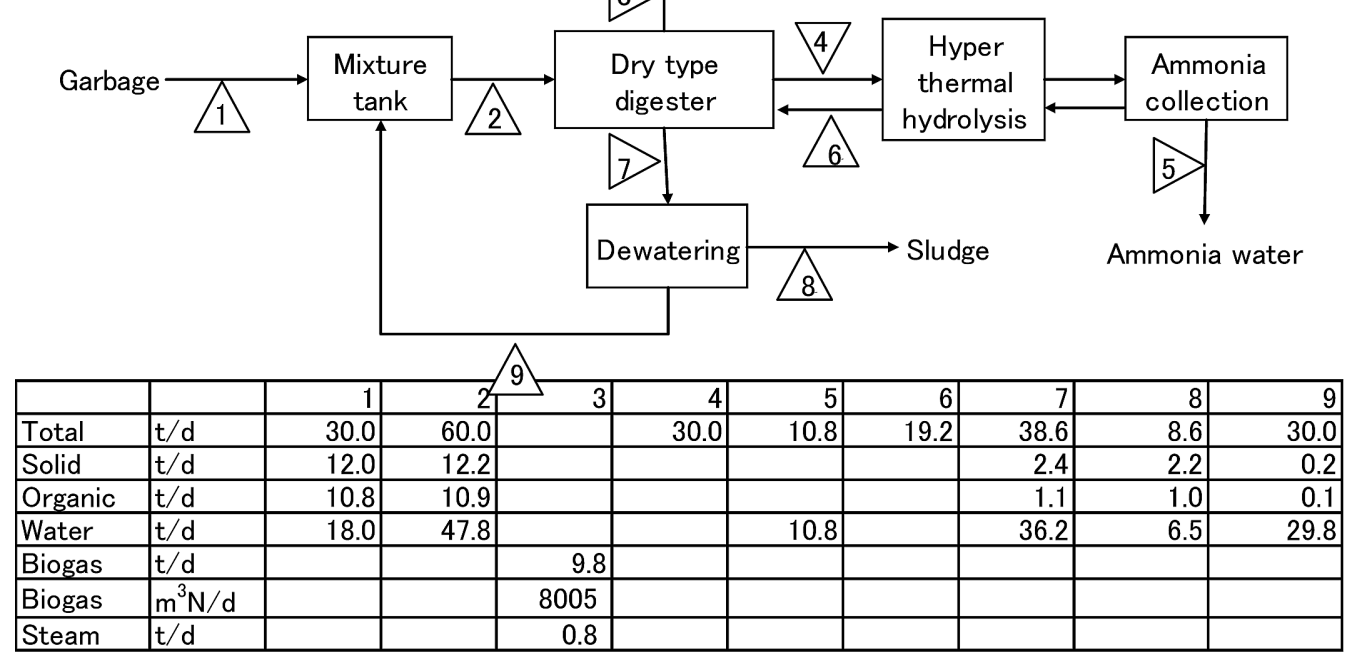

Fig. 2 Material balance

超高温可溶化導入条件では 8.6t/ 日と 39\%減少する。

\section{4 エネルギー収支計算の前提条件}

エネルギー収支の計算に用いる，各単位プロセスに要する 必要電力量は Table 3 の通りとした。

メタン発酵槽及び超高温可溶化槽への導入のための加温は 温水で行うこととし，メタン発酵槽に扔ける放熱は，両条件 で差がないため考慮しないこととするが，超高温可溶化槽に 導入するための加温の際には $10 \%$ の放熱があると想定した。

アンモニアストリッピングの際に水蒸気が奪う潜熱は蒸気 によって補うこととした。

回収したバイオガスはバイオガスエンジンに供給し，40\%

Table 3 Electric energy required for each unit process

\begin{tabular}{l|l}
\hline Dry type anaerobic digester & $70 \mathrm{kWh} / \mathrm{t}$-garbage ${ }^{10)}$ \\
\hline Water treatment & $47 \mathrm{kWh} / \mathrm{t}$-garbage ${ }^{10)}$ \\
\hline AS & $0.002 \mathrm{kWh} / \mathrm{m}^{3}$-stripping gas ${ }^{11)}$ \\
\hline
\end{tabular}

*AS: Ammonia stripping
が電力, $20 \%$ が蒸気， $20 \%$ が温水に変換されるものとした ${ }^{12)} 。$

\section{3. 結果と考察}

両フローのエネルギーバランスをTable 4に示す。電力に関 しては，“エネルギーの使用の合理化に関する法律 (通称，省

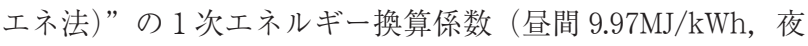
間 $9.28 \mathrm{MJ} / \mathrm{kWh})$ の昼間と夜間の時間を考慮した加重平均值 $9.68 \mathrm{MJ} / \mathrm{kWh}$ 使用して 1 次エネルギーに換算した。超高温可 溶化を採用したフローでは，メタン回収量が10\%増大するこ と, および排水処理が不要となるため標準フローに比べ電力 消費量を $39 \%$ 削減できることから余剩電力は $17 \%$ 増大した。 超高温可溶化槽での水の気化熱を供給するための蒸気が必要 となるため, 回収エネルギーの総量での比較では, 超高温可 溶化を採用したほうが 5 \%増大した。

超高温可溶化の採用による回収される余剩エネルギーの増 加量は $5 \%$ であるが，標準フローで回収されるエネルギーの $72 \%$ が蒸気及び温水という熱であるのに対し, 超高温可溶化 導入を採用したフローでは $83 \%$ を電力として回収することが 
Table 4 Comparison of energy balance

\begin{tabular}{|c|c|c|c|c|c|}
\hline & & \multicolumn{2}{|c|}{ Standard } & \multicolumn{2}{|c|}{ With HTH } \\
\hline Input & Garbage & $30 t$ & $228 \mathrm{GJ}$ & $30 t$ & $228 \mathrm{GJ}$ \\
\hline Output & Biogas & $7293 \mathrm{t}$ & $175 \mathrm{GJ}$ & $8005 t$ & $192 \mathrm{GJ}$ \\
\hline \multirow{5}{*}{$\begin{array}{c}\text { Recovered } \\
\text { energy }\end{array}$} & \multirow{2}{*}{ Electlicity } & BCG & $19,448 \mathrm{kWh}$ & BCG & $21,346 \mathrm{kWh}$ \\
\hline & & & $188 \mathrm{GJ}$ & & $207 \mathrm{GJ}$ \\
\hline & Steam & BCG & $35 \mathrm{GJ}$ & BCG & $38 \mathrm{GJ}$ \\
\hline & Hot water & BCG & $35 \mathrm{GJ}$ & BCG & $38 \mathrm{GJ}$ \\
\hline & Total & BCG & $258 \mathrm{GJ}$ & $\mathrm{BCG}$ & $283 \mathrm{GJ}$ \\
\hline \multirow{10}{*}{$\begin{array}{c}\text { Consumed } \\
\text { Energy }\end{array}$} & \multirow{5}{*}{ Electlicity } & Anaerobic digester & $-2,100 \mathrm{kWh}$ & Anaerobic digester & $-2,100 \mathrm{kWh}$ \\
\hline & & $\mathrm{HTH}$ & $0 \mathrm{kWh}$ & $\mathrm{HTH}$ & $-30 \mathrm{kWh}$ \\
\hline & & Water treatment & $-1,410 \mathrm{kWh}$ & Water treatment & $0 \mathrm{kWh}$ \\
\hline & & Total (Electlicity) & $-3,510 \mathrm{kWh}$ & Total (Electlicity) & $-2,130 \mathrm{kWh}$ \\
\hline & & & $-34 \mathrm{GJ}$ & & $-21 \mathrm{GJ}$ \\
\hline & Steam & AS & $0 \mathrm{GJ}$ & AS & $-25 \mathrm{GJ}$ \\
\hline & \multirow{3}{*}{ Hot water } & Anaerobic digester & $-10 \mathrm{GJ}$ & Anaerobic digester & $-10 \mathrm{GJ}$ \\
\hline & & $\mathrm{HTH}$ & $0 \mathrm{GJ}$ & $\mathrm{HTH}$ & $-3 \mathrm{GJ}$ \\
\hline & & Total (Hot water) & $-10 \mathrm{GJ}$ & Total (Hot water) & $-13 \mathrm{GJ}$ \\
\hline & Total & & $-44 \mathrm{GJ}$ & & $-59 \mathrm{GJ}$ \\
\hline \multirow{5}{*}{$\begin{array}{l}\text { Surplus } \\
\text { energy }\end{array}$} & \multirow{2}{*}{ Electlicity } & & $15,938 \mathrm{kWh}$ & & $19,216 \mathrm{kWh}$ \\
\hline & & & $154 \mathrm{GJ}$ & & $186 \mathrm{GJ}$ \\
\hline & Steam & & $35 \mathrm{GJ}$ & & $14 \mathrm{GJ}$ \\
\hline & Hot water & & $25 \mathrm{GJ}$ & & $25 \mathrm{GJ}$ \\
\hline & Total & & $214 \mathrm{GJ}$ & & $225 \mathrm{GJ}$ \\
\hline
\end{tabular}

Each figures show the energy amount a day *HTH: Hyper thermal hydrolysis

*BCG: Biogas co-generation

できる。熱，特に温水は利用用途の狭い低級なエネルギーで あるのに対し，電力は用途の広い高級なエネルギーであり，余 剩エネルギーに占める電力の割合が高いことから，超高温可 溶化導入のメリットは大きいと言える。

さらに，既に述べたように，超高温可溶化を導入した場合 は排水処理が不要となり, 残渣の発生量も約 4 割減少するこ とから，これらの処理・処分に必要なコストが大幅に削減さ れ，経済的にも大幅に有利となると考えられる。

超高温可溶化導入の場合の懸念材料は，脱水ろ液を希䣋水 として利用することによりメタン発酵槽内でメタン発酵阻害 物質（アンモニア，塩類等）が濃縮されることであるが，十 分な量のガスでアンモニアストリッピングをすることで，ア ンモニアによる阻害が発生することは防ぐことができる。メ タン発酵が強く阻害されるアンモニア性窒素濃度は, 中温発 酵で $5,000 \mathrm{mg} / \mathrm{L}$ 程度，高温発酵で 2,500-3,000mg/L 程度とさ れているが6)7)，筆者らはモデルケースの生ごみを超高温可溶 化導入フローで処理することにより約 $1,500 \mathrm{mg} / \mathrm{L}$ と問題のな いアンモニア濃度で維持できることを実験的に確認した。

無機物についても，物質収支で示したように，発酵残渣と して一部が系から除去されることで非常に低い濃度で平衡に 達すると考えられ，問題とはならない可能性が高い。

\section{4. まとめ}

本試算の結果, 超高温可溶化の導入により排水処理不要の メタン発酵システムが構築できる可能性が示唆された。アン モニアストリッピングで回収されたアンモニア水は焼却排熱 で濃縮し，焼却炉の脱硝用アンモニアとして利用することが できる。またメタン発酵の脱水残渣も焼却炉で焼却できるこ とから, 残渣・排水処理不要のメタン発酵施設を提案するこ とができる(Fig. 3参照)。さらに，本プロセスはエネルギー 収支上は従来プロセスとほとんど変わらないが，付加価值の 高い電力として回収できるエネルギーの割合が高くなること

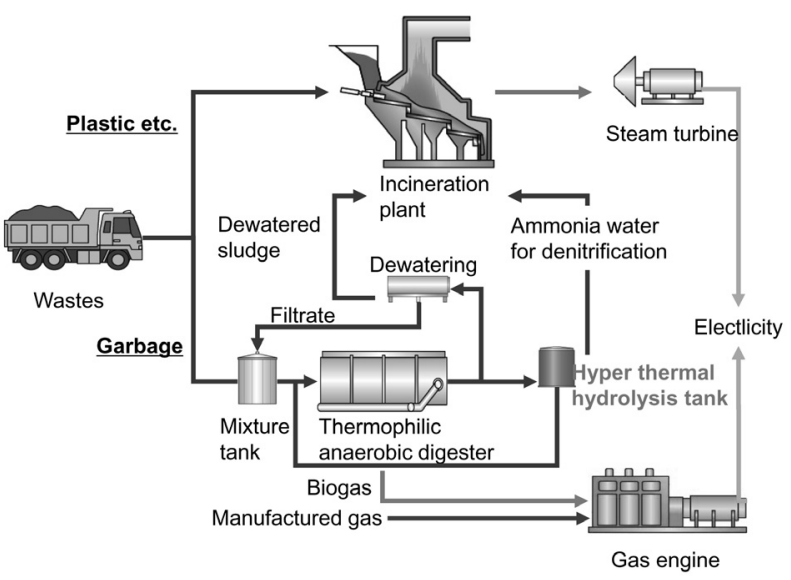

Fig. 3 Flow chart of waste incineration plant attached by methane fermentation plant 
から，エネルギー回収の観点からも従来プロセスと比較して 有利となることが示唆された。

\section{文 献: References}

1）益田光信，環境技術, 29 (9), 669-670 (2000)：Masuda, M., Kankyo Gijutsu, 29 (9), 669-670(2000)

2) Speece, R. E. (松井三郎，高島正信監訳)，産業廃水処理の ための嫌気性バイオテクノロジー，(技報堂出版）, (1999)

3) 高島正信, 水処理技術, 45(5), 207-213(2004): Takashima, M., Mizushorigijutsu, 45(5), 207-213(2004)

4）坪田潤，局俊明，菅原正孝，濱崎竜英，津野洋，廃棄物学 会論文誌, 18(4), 240-249(2007)：Tsubota, J. et al., Waste Management Research, 18(4), 240-249 (2007)

5）坪田潤, 黒木浩二, 洪鋒, 千智勲, 津野洋, 廃棄物学会論 文誌, 19(4), 265-274(2008)：Tsubota, J. et al., Waste Management Research, 9 (4), 265-274(2008)
6) Angelidaki, I., Ahring, B. K., Water Res., 28, 727-731 (1994)

7）船石圭介, 山下耕司, 佐々木宏, 李玉友, 第34回日本水 環境学界年会講演集，pp. 416 (2002)：Funaki, K., et al., The 34th Japan Society on Water Environment Annual Meeting, pp. 416 (2002)

8) Saracco, G., Genon G. J., Mater., 37, 191-206(1994)

9）坪田潤, 角新支朗, 津野洋, 廃衰物学会論文誌, 19(1), 5160 (2008) : Tsubota, J. et al., Waste Management Research, 19 (1), 51-60 (2008)

10）平成 18 年度環境省受託業務報告書，バイオ資源・廃棄物 等からの水素製造技術開発

11）（社）日本下水道協会，下水道施設計画 - 設計指針と解説後 編，pp. 104-105(2001)

12) Yenbacher社ホームページ(ガスエンジン仕様), http:// www.ge-energy.com/prod_serv/products/recip_engines/ en/downloads/type3_en_new.pdf(2006.12) 